\title{
FUNCTIONAL INEQUALITIES FOR MODIFIED STRUVE FUNCTIONS II
}

\author{
ÁRPÁD BARICZ AND TiBOR K. POGÁNY
}

\begin{abstract}
In this paper our aim is to prove some monotonicity and convexity results for the modified Struve function of the second kind by using its integral representation. Moreover, as consequences of these results, we present some functional inequalities (like Turán type inequalities) as well as lower and upper bounds for modified Struve function of the second kind and its logarithmic derivative.
\end{abstract}

Mathematics subject classification (2010): 33C10, 39B62.

Keywords and phrases: Modified Struve function, modified Bessel function, Turán type inequality.

\section{REFERENCES}

[1] Á. BARICZ, Turán type inequalities for modified Bessel functions, Bull. Austr. Math. Soc. 82, 2 (2010), 254-264.

[2] Á. BARICZ, Bounds for modified Bessel functions of the first and second kinds, Proc. Edinb. Math. Soc. 53, (2010), 575-599.

[3] Á. Baricz And T. K. Pogány, Functional inequalities for modified Struve functions, Proc. Roy. Soc. Edinburgh Sect. A (in press).

[4] C. M. Joshi And S. Nalwaya, Inequalities for modified Struve functions, J. Indian Math. Soc. 65, (1998), 49-57.

[5] C. H. Kimberling, A probabilistic interpretation of complete monotonicity, Aequationes Math. 10, (1974), 152-164.

[6] D. S. Mitrinović, Analytic Inequalities, Springer-Verlag, Berlin, 1970.

[7] F. W. J. Olver, D. W. Lozier, R. F. Boisvert and C. W. Clark (Eds.), NIST Handbook of Mathematical Functions, Cambridge University Press, Cambridge, 2010.

[8] T. K. Pogány And H. M. SRIVAstava, Some Mathieu-type series associated with the Fox-Wright function, Comput. Math. Appl. 57, 1 (2009), 127-140.

[9] F. QI, Bounds for the ratio of two gamma functions, J. Inequal. Appl. (2010), Art. 493058.

[10] V. R. ThiRUVEnKaTACHAR AND T. S. NANJUndiaH, Inequalities concerning Bessel functions and orthogonal polynomials, Proc. Ind. Acad. Sci. Sect. A 33, (1951), 373-384.

[11] D. V. WIDDER, The Laplace Transform, Princeton Univ. Press, Princeton, 1941. 